\title{
Wykorzystanie skali Hammersmith Infant Neurological Examination u niemowląt w celu przewidywania lub potwierdzenia wystąpienia mózgowego porazenia dziecięcego - systematyczny przegląd piśmiennictwa
}

\author{
Using the Hammersmith Infant Neurological Examination Scale in infants to predict or \\ confirm cerebral palsy - a systematic literature review
}

\author{
Klaudia Maćkowska (D), Marta Raźniewska (D), Gabriela Siwiec (D), Justyna Skrzypczak (iD, Katarzyna \\ Ostrzyżek-Przeździecka* D, Jakub S. Gąsior* iD \\ Oddział Fizjoterapii, Wydział Medyczny, Warszawski Uniwersytet Medyczny \\ *Klinika Kardiologii Wieku Dziecięcego i Pediatrii Ogólnej, Warszawski Uniwersytet Medyczny \\ DOI:10.20966/chn.2020.59.470
}

\section{STRESZCZENIE}

Wstęp: W literaturze anglojęzycznej opisane zostało wiele narzędzi pozwalających na ocenę stanu neuromotorycznego noworodków i niemowląt. Celem niniejszej pracy jest przedstawienie w polskiej literaturze medycznej skali Hammersmith Infant Neurological Examination (HINE) oraz przeprowadzenie systematycznego przeglądu piśmiennictwa dotyczącego stosowania jej u niemowląt w predykcji mózgowego porażenia dziecięcego (MPD). Metoda: Przeszukano medyczną bazę danych MEDLINE PubMed używając następujących zwrotów kluczowych: cerebral palsy w połączeniu z Hammersmith Infant Neurological Examination, znajdujących się $w$ tytule i/lub streszczeniu publikacji. Dodatkowym kryterium włączenia był język angielski publikacji. Wyniki: Zidentyfikowano łącznie 22 publikacje. Pierwsza analiza pozwoliła wykluczyć 7 badań niespełniających kryteriów włączenia do szczegótowej analizy. Bazując na wynikach analizowanych badań można stwierdzić, że wynik HINE poniżej 66 punktów uzyskany w 3, 6, 9 i/lub 12 miesiącu życia wskazuje na ryzyko wystąpienia MPD w późniejszym etapie życia dziecka.

Wnioski: Skala HINE jest użytecznym narzędziem wykorzystywanym już w pierwszych miesiącach życia dziecka do oceny ryzyka wystąpienia zaburzeń neurorozwojowych, w tym MPD. Umożliwia wczesne wykrycie zespołu zaburzeń, co jest szczególnie istotne w zaplanowaniu dalszego odpowiedniego leczenia. Zaleca się połączenie badania neurologicznego HINE $\mathrm{z}$ badaniem metodą Prechtla oraz badaniami neuroobrazowymi w celu zwiększenia mocy predykcyjnej. Jednakże, ze względu na wysoką czułość obu narzędzi, w codziennej praktyce klinicyści mogą zdecydować się na użycie tylko jednego z nich (HINE lub ocena wg Prechtla). Mimo ogólnodostępnej i nieskomplikowanej formy badania, HINE nie znajduje jednak szerokiego zastosowania u klinicystów, co, bez wątpienia, powinno ulec zmianie.

Słowa kluczowe: mózgowe porażenie dziecięce, Hammersmith Infant Neurological Examination

\section{ABSTRACT}

Introduction: Many methods have been described in the English-language literature to assess the neuromotor condition of newborns and infants. The aim of the study was to present the Hammersmith Infant Neurological Examination (HINE) scale in the Polish medical literature and to review the systematic literature on the use of HINE in infants at risk of cerebral palsy. Methods: MEDLINE PubMed medical database was searched using the following key phrases: cerebral palsy in conjunction with Hammersmith Infant Neurological Examination, in the title and/or abstract of the publication. An additional inclusion criterion was the English language of the publication.

Results: The 22 identified publications had been selected for the analysis. The first analysis ruled out seven studies that did not meet the inclusion criteria for detailed analysis. Based on the results of the analyzed studies, it can be concluded that the HINE result below 66 points obtained at 3, 6, 9 and/or 12 months of life indicates the risk of CP later in the child's life.

Conclusion: The HINE scale is a useful tool used in the first months of a child's life to assess the risk of developing neurodevelopmental disorders, including CP. This scale enables early detection of disorders, which is particularly important in planning further appropriate treatment. It is recommended to combine HINE with Prechtl examination and neuroimaging in order to increase the predictive power. However, due to the high sensitivity of both tools, clinicians may choose to use one of them in daily practice (HINE or Prechtl's assessment). Despite the widely available and uncomplicated form of the study, HINE is not widely used by clinicians, which undoubtedly should be change.

Key words: cerebral palsy, Hammersmith Infant Neurological Examination

\section{INTRODUKCJA}

Różne definicje mózgowego porażenia dziecięcego (MPD) pojawiały się w literaturze medycznej na przestrzeni lat. Próbę usystematyzowania wiedzy na temat MPD podjęli w 2006 roku Rosenbaum i wsp. [1]. Zgodnie z zaproponowaną przez autorów definicją, MPD to grupa

trwałych zaburzeń rozwoju ruchu i postawy wynikających z niepostępującego uszkodzenia rozwijającego się mózgu płodu lub niemowlęcia. W konsekwencji obserwujemy w tej grupie pacjentów ograniczenia motoryczne, którym często towarzyszą zaburzenia czucia, percepcji i funkcji 
poznawczych, komunikacji, zachowania, a także padaczkę oraz wtórne powikłania ze strony układu mięśniowo-szkieletowego [1].

Przyczyny wystąpienia MPD są złożone i niejednorodne. Ich charakter może mieć podłoże zapalne, pourazowe, wrodzone, zakaźne lub metaboliczne. Bardzo często klinicyści nie są w stanie wskazać konkretnej przyczyny wystąpienia tej grupy zaburzeń u danego pacjenta [2]. W literaturze opisano wiele czynników, które zwiększają ryzyko wystąpienia MPD w okresie prenatalnym, okołoporodowym i poporodowym. Część czynników ryzyka związanych jest z sytuacją socjodemograficzną matki oraz historią poprzednich porodów [3]. Czynniki ryzyka okresu prenatalnego to infekcje wewnątrzmaciczne, a także wewnątrzmaciczne zahamowanie wzrostu i rozwoju płodu. Szacuje się, że stanowią one przyczynę około 70\% przypadków wystąpienia MPD ogólnie, oraz około 55\% przypadków postaci czterokończynowej. W okresie okołoporodowym największe ryzyko MPD niesie za sobą poród przedwczesny (około 35\% przypadków), zwłaszcza skrajne wcześniactwo. Inne czynniki predysponujące do wystąpienia MPD w okresie okołoporodowym to aspiracja smółki, krwawienie dokomorowe, hiperbilirubinemia, zespół zaburzeń oddychania, niedotlenienie oraz drgawki noworodkowe. Okres poporodowy, w którym mogą pojawić się objawy MPD obejmuje czas od końca okresu noworodkowego do 5 roku życia dziecka. Ryzyko wystąpienia zespołu zaburzeń w tym przedziale czasu zwiększa zapalenie opon mózgowych, uraz głowy bądź podtopienie się dziecka [2, 3].

Badanie neurologiczne i/lub stanu neuromotorycznego noworodków i niemowląt przeprowadza się w celu oceny rozwoju psychoruchowego. Aby uzyskać kompleksowy obraz stanu neurologicznego pacjenta należy przeprowadzić dokładną ocenę funkcji czuciowych i motorycznych, ocenę nerwów czaszkowych oraz badanie odruchów neurologicznych. Informacje zebrane przy badaniu mogą stanowić podstawę do postawienia diagnozy oraz pomagają w planowaniu dalszej terapii [4]. Podczas oceny neurologicznej należy zwrócić szczególną uwagę na wszelkie nieprawidłowości w kontroli postawy i motoryki. Oceniając postawę dziecka ważne jest, aby ocenić ustawienie tułowia, głowy oraz kończyn. W ocenie motoryki niepokojący może być ubogi repertuar spontanicznych ruchów kończyn, brak płynności ruchu oraz nieprawidłowości w zakresie odruchów wrodzonych, rozwoju reakcji odruchowych i równoważnych. Występowanie podwyższonego lub obniżonego napięcia mięśniowego osiowego i/lub kończyn jest sygnałem alarmującym [5-7].

Do podstawowych narzędzi oceny ryzyka wystąpienia MPD możemy zaliczyć obrazowanie metodą rezonansu magnetycznego, badanie globalnych wzorców ruchu metodą Prechtla (ang. Prechtl's General Movements Assessment) oraz skalę HINE (ang. Hammersmith Infant Neurological Examination) będącą prostą metodą punktacji zdolności motorycznych u dzieci od 2 do 24 miesiąca życia [8, 9].

Skala HINE składa się z trzech części: pierwszej stanowiącej badanie neurologiczne włączające ocenę: czynności nerwów czaszkowych, postawy ciała, ruchów, napięcia mięśniowego, odruchów i reakcji; drugiej pozwalają- cej na ocenę 8 pozycji bazujących na wybranych etapach rozwoju motorycznego dziecka; oraz trzeciej oceniającej zachowanie. Pacjent oceniany z użyciem skali HINE może uzyskać maksymalnie 78 punktów [10]. Badając różne grupy wiekowe określono zakres wartości optymalnych na danym etapie rozwojowym dziecka: między 12 a 16 tygodniem życia: 62.5-69 punktów; między 16 a 20 tygodniem życia: 65.5-74 punkty; między 20 a 24 tygodniem życia: $61.5-74$ punkty; między 24 a 28 tygodniem życia: 69-76.5 punktów; między 28 a 32 tygodniem życia: 72-78 punktów; w 12 miesiącu życia: 63-78 punktów [11, 12]. Badanie neurologiczne HINE, z wykazaną wysoką czułością sięgającą 90\% [8], pozwala na ocenę ryzyka lub wczesną diagnozę zaburzeń neurologicznych, co jest niezwykle istotne dla procesu neuroplastyczności mózgu, szybkiego wdrożenia odpowiedniego postępowania i interwencji terapeutycznej, a w konsekwencji, dla zmniejszenia ryzyka lub zapobiegania wystąpienia wtórnych powikłań [9].

Celem przedstawionej pracy jest systematyczny przegląd piśmiennictwa dotyczącego wykorzystania skali HI$\mathrm{NE}$ u dzieci w wieku niemowlęcym do przewidywania wystąpienia MPD.

\section{MATERIAŁ I METODY}

Przeszukano medyczną bazę danych MEDLINE PubMed używając następujących słów kluczowych: cerebral palsy w połączeniu z Hammersmith Infant Neurological Examination, znajdujących się w tytule i/lub streszczeniu publikacji (link do wyszukiwania z dnia 08.04.2021): https://pubmed.ncbi.nlm.nih.gov/?term $=(\% 22$ cerebral $\% 20$ palsy $\% 22 \% 5$ B Title $\% 2$ FAbstract $\% 5$ D) $\% 20$ AND $\% 20(\% 22$ Hammersmith\%20Infant $\% 20$ Neurological $\% 20$ Examination $\% 22 \% 5$ BTitle $\% 2$ FAbstract $\% 5 D) \&-$ page $=2$

Do szczegółowej analizy włączono badania wykorzystujące skalę HINE w przewidywaniu wystąpienia MPD oraz badania, w których HINE stanowiło element oceny rozwoju motorycznego dzieci z rozpoznanym MPD. Dodatkowym kryterium był język publikacji, włączono jedynie publikacje napisane w języku angielskim. Systematyczny przegląd piśmiennictwa został przeprowadzony zgodnie z rekomendacjami PRISMA statement (ang. Preferred Reporting Items for Systematic Reviews and Meta-Analyses) [13]. Rekomendacje PRISMA przedstawiają zestaw elementów niezbędnych do prawidłowego raportowania systematycznych przeglądów literatury i/lub metaanaliz. Dokument składa się z 27-częściowej listy kontrolnej i czteropoziomowego diagramu przedstawiającego sekwencję kolejnych etapów przeprowadzania przeglądu [13].

\section{WYNIKI}

Po przeszukaniu wybranej medycznej bazy danych zidentyfikowano 22 publikacje, w tym 5 przeglądów piśmiennictwa. Wyłączono jedną publikację oceniającą narzędzia kliniczne u niemowląt z opóźnieniem poznawczym i motorycznym bez MPD, jedną stanowiącą protokół randomizowanego kontrolowanego badania klinicznego oraz jedną, w której grupę badaną stanowili klinicyści [14]. Ostatecznie do przeglądu włączono i poddano szczegóło- 
wej analizie 14 publikacji wykorzystujących narzędzie HINE (Rycina 1). Dodatkowym narzędziem wykorzystanym przez część badaczy w swoich pracach była skala Bayley II [10, 15-17] oraz metoda oceny globalnych wzorców ruchowych według Prechtla $[9,18]$. Szczegółowe wyniki niniejszego przeglądu zostały przedstawione w formie tabelarycznej, uwzględniając cel badania, charakterystykę grup badanych, interwencję terapeutyczną oraz wyniki (Tabela I).

Ryc 1. Proces selekcji badań

Figure 1. Screening process

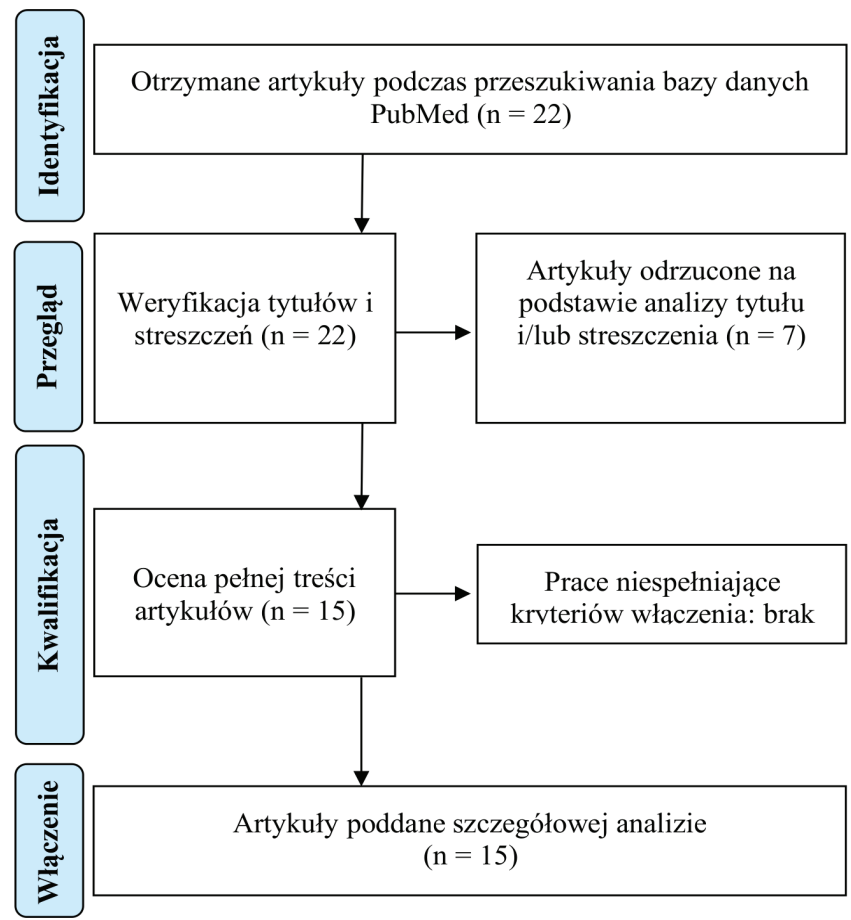

\section{DYSKUSJA}

Do niedawna z postawieniem diagnozy MPD wstrzymywano się do okresu między 12 a 24 miesiącem życia dziecka [8]. Dziś, dzięki zwalidowanym skalom, testom i narzędziom diagnostycznym wykorzystywanym w połączniu $\mathrm{z}$ badaniem neuroobrazowym klinicyści mogą zdiagnozować MPD u dziecka w wieku poniżej 5 miesiąca życia [8]. W prezentowanej pracy przedstawiono badanie neurologiczne HINE oraz dokonano systematycznego przeglądu piśmiennictwa dotyczącego wykorzystania badania u dzieci w wieku niemowlęcym, w celu przewidywania wystąpienia w późniejszym czasie zespołu zaburzeń rozwoju narządu ruchu i postawy jakim jest MPD.

Bazując na wynikach włączonych badań można stwierdzić, że wynik HINE poniżej 66 punktów uzyskany w pierwszych 12 miesiącach życia (3, 6, 9 miesiąc) sugeruje diagnozę MPD w późniejszym etapie życia. W 2017 Novak i wsp. przedstawili systematyczny przegląd piśmiennictwa prezentujący udokumentowane naukowo metody diagnostyczne, których określone wyniki pozwalają na wczesne i trafne rozpoznanie MPD [8]. Wynik HINE poniżej 57 punktów w 3 miesiącu życia, oraz poniżej 40 punktów w 6, 9 i 12 miesiącu życia pozwala określić z prawie $100 \%$ pewnością wystąpienie w przyszłości u dziecka MPD [8]. Mniejsza ilość punktów uzyskanych w badaniu HINE związana była z cięższą postacią MPD [8].

Włączone do niniejszego przeglądu badania miały różne cele. W związku z tym, dokonano podziału artykułów ujętych w wynikach na dwie grupy badań. Jedną z nich stanowią publikacje, w których badanie HINE wykonywano w pierwszych miesiącach życia dziecka, przed diagnozą MPD [9, 10, 17-19, 21-23]. Wyniki badań przedstawione w tych pracach są bezpośrednią odpowiedzią na postawiony cel pracy. Na ich podstawie można stwierdzić, iż HINE wykazuje wysoką czułość i swoistość, jednak najlepsze wyniki można osiągnąc łącząc to badanie $\mathrm{z}$ innymi metodami oceny, takimi jak ocena globalnych wzorców ruchowych wg Prechtla, MRI i USG, czego potwierdzenie możemy zaobserwować w dostępnej literaturze [8].

Niski wynik HINE w wieku niemowlęcym skorelowany był z opóźnionym rozwojem motorycznym dziecka [19, 17, 22, 23]. Dzieci ze zdiagnozowanym MPD, w okresie niemowlęcym prezentowały wyniki HINE znacznie niższe od normy $[10,17,21]$. Co więcej, dzięki badaniu HINE możliwe jest nie tylko wczesne diagnozowanie MPD, ale również przewidywanie typu oraz stopnia ciężkości MPD [17]. Znaczenie predykcyjne HINE zostało udowodnione obszernymi badaniami, w których metoda ta wyróżniła się wysoką czułością i swoistością [10].

Druga grupa publikacji to prace pośrednio związane $\mathrm{z}$ celem przeglądu, w których HINE stanowiło jedno z narzędzi diagnostycznych do stwierdzenia MPD bądź do ewaluacji nasilenia zaburzeń neurorozwojowych (w większości badań w 2 roku życia dziecka) [15, 16, 20, 24, 25]. Niższe wyniki HINE uzyskiwały dzieci, u których w okresie noworodkowym stwierdzono patologie w obrębie mózgu $[15,20]$ oraz, u których rozpoznano zaburzenia neurorozwojowe [16]. Dzieci z porażeniem czterokończynowym uzyskiwały znacznie niższe wyniki HINE, niż dzieci z inną postacią MPD [25]. Wyniki dzieci bez MPD były istotnie wyższe niż wyniki pacjentów z hemiplegią [24]. Autorzy prac zakwalifikowanych do przeglądu wykorzystywali również badanie GMA [9, 18] w celu oceny funkcjonalnej OUN (ośrodkowy układ nerwowy) oraz skalę Bayley, aby ocenić funkcje poznawcze oraz motorykę małą i dużą w 2 roku życia wieku skorygowanego [10, 15-17, 23, 25].

Kompleksowa diagnostyka niemowląt w celu predykcji zaburzeń neurorozwojowych oparta jest na stosowaniu badań neuroobrazowych (MRI lub USG), oceny globalnych wzorców ruchowych metodą Prechtla i badania neurologicznego HINE [8]. Morgan i wsp. w swojej pracy przedstawili wyniki uzyskane z wykorzystaniem wymienionych wyżej narzędzi, które w połączeniu wykazują wysoką moc predykcyjną. Uzupełniając się pozwalają uzyskać czułość i swoistość oceny neurologicznej sięgającą kolejno 98\% i 99\% [9]. Według Romeo i wsp. wykorzystywanie badania neurologicznego jakim jest Hammersmith Infant Neurological Examination pomaga w skutecznym przewidywaniu wyników neurorozwojowych u niemowląt, a w połączeniu z oceną ruchów globalnych wg Prechtla staje się dobrym narzędziem do wczesnego rozpoznania MPD oraz 
rozróżnienia jego postaci [27]. Zintegrowane stosowanie tych metod powinno uzupełniać inne badania, aby przynieść jak najlepsze efekty we wczesnej ocenie neurorozwojowej niemowląt [9]. Jednakże ze względu na wysoką czułość obu narzędzi zastosowanie tylko jednego z nich, tj. HINE lub oceny wg Prechtla jest wystarczające w codziennej praktyce klinicznej.

W kwietniu 2021 roku zostało opublikowane badanie, którego autorzy analizowali związek wyników uzyskanych w badaniu HINE przez dzieci urodzone przedwcześnie $\mathrm{w}$ ich drugim roku życia z rozwojem poznawczym ocenionym w 11 roku życia [28]. Wynik badania HINE przeprowadzonego w wieku 2 lat może pomóc w wykrywaniu ryzyka upośledzenia funkcji poznawczych w wieku 11 lat u dzieci urodzonych przedwcześnie, które rozwiną lub nie MPD. Ponadto, uzyskanie wyższych wartości badania HINE w 2 roku życia było związane z wyższym poziomem inteligencji ocenianym w 11 roku życia [28]. Związek pomiędzy wczesnym nabywaniem umiejętności motorycznych i późniejszymi umiejętnościami poznawczymi jest coraz częściej badanym zagadnieniem [29]. U dzieci rozwój motoryczny stymuluje interakcję ze środowiskiem, co skutkuje postępem w rozwoju różnych umiejętności poznawczych poprzez tworzenie nowych możliwości uczenia się [30]. Opublikowany w 2017 roku e-book pod redakcją Petry Hauf i Klausa Libertusa zawiera 28 publikacji naukowych analizujących związek pomiędzy domeną motoryki, a innymi zagadnieniami związanymi z rozwojem dziecka [31].

Mimo rosnącej świadomości personelu medycznego o możliwościach diagnostycznych HINE, nie jest to metoda powszechnie stosowana. Zgodnie $\mathrm{z}$ doniesieniami Williams i wsp. [32], niespełna 50\% klinicystów nigdy nie stosowało badania HINE do oceny dzieci zagrożonych MPD w wieku poniżej pierwszego roku życia. Ponadto, 57\% spośród badanych nigdy nie użyło metody HINE u dzieci między pierwszym, a drugim rokiem życia. Fakt niekorzystania z badania HINE przez badanych jest tym bardziej zaskakujący, iż prawie $80 \%$ medyków zadeklarowało znajomość wykorzystania powyższego badania w diagnozowaniu MPD [32].

Liczne badania potwierdzają, że HINE odgrywa istotną rolę $\mathrm{w}$ diagnostyce niemowląt dając dobre wyniki w predykcji MPD. Ogromną zaletą badania neurologicznego HINE jest fakt, że jest wystandaryzowanym i zwalidowanym narzędziem, które można zastosować u niemowląt już od 2 miesiąca życia. Niewątpliwym walorem tego badania jest również jego krótki czas realizacji, łatwość w wykonaniu, nawet w przypadku mniej doświadczonego personelu, oraz ogólnodostępność. Formularz badania dostępny jest na stronie internetowej http://hammersmith-neuro-exam. com/recording-scoring-proformas/ wraz z wersją polskoję-

Tab. I. Systematyczny przegląd piśmiennictwa skali HINE w celu przewidywania lub potwierdzenia wystąpienia MPD. Systematic review of the HINE scale to predict or confirm the occurrence of CP.

\begin{tabular}{|c|c|c|c|c|c|}
\hline $\begin{array}{c}\text { Autor } \\
\text { i rok } \\
\text { publikacji } \\
\text { Author and } \\
\text { the year of } \\
\text { publication }\end{array}$ & $\begin{array}{c}\text { Cel badania } \\
\text { Aim of the study }\end{array}$ & $\begin{array}{c}\text { Przeprowa- } \\
\text { dzone badanie } \\
\text { neurologiczne } \\
\text { Neurological } \\
\text { examination } \\
\text { performed }\end{array}$ & $\begin{array}{l}\text { Charakterystyka } \\
\text { grup badanych } \\
\text { Characteristic of the } \\
\text { studied groups }\end{array}$ & $\begin{array}{l}\text { Interwencja } \\
\text { terapeuty- } \\
\text { czna } \\
\text { Therapeutic } \\
\text { intervention }\end{array}$ & $\begin{array}{l}\text { Wyniki } \\
\text { Results }\end{array}$ \\
\hline $\begin{array}{l}\text { Ricci i wsp. } \\
\text { (2006) } \\
{[19]}\end{array}$ & $\begin{array}{l}\text { 1. Badanie za pomocą } \\
\text { HINE niemowląt } \\
\text { w wieku 6-9 msc. } \\
\text { (wiek skorygowany) } \\
\text { z leukomalacją } \\
\text { okołokomorową. } \\
\text { 2. Ocena istnienia } \\
\text { związku między } \\
\text { wynikami HINE } \\
\text { a wystąpieniem } \\
\text { zaburzeń rozwoju } \\
\text { motorycznego w wieku } \\
2 \text { lat }\end{array}$ & HINE & 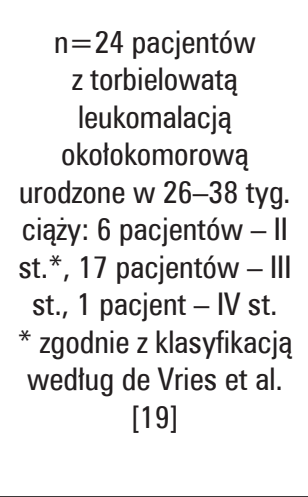 & Brak & $\begin{array}{c}18 \text { niemowląt rozwinęło MPD; } \\
\text { HINE > 60: } \mathrm{n}=7 \text {, zdolne do } \\
\text { samodzielnego chodu w wieku } 2 \text { lat } \\
\text { (1 pacjent } \mathrm{z} \text { diplegią, } 6 \text { pacjentów } \\
\text { bez MPD); } \\
\text { HINE } 60-41: \mathrm{n}=11 \text {, brak } \\
\text { samodzielnego chodu, } \mathrm{n}=9 \\
\text { samodzielnie siadało (4 pacjentów } \\
\text { z tetraplegią, } 7 \text { pacjentów z diplegią); } \\
\text { HINE < 40: } \mathrm{n}=6 \text {, brak } \\
\text { samodzielnego siadu w wieku } 2 \text { lat } \\
\text { (6 pacjentów z tetraplegią). }\end{array}$ \\
\hline $\begin{array}{l}\text { Luciano i wsp. } \\
\qquad \begin{array}{c}(2007) \\
{[20]}\end{array}\end{array}$ & $\begin{array}{l}\text { Ocena występowania } \\
\text { i ciężkości objawów } \\
\text { neurologicznych } \\
\text { oraz zaburzeń } \\
\text { poznawczych w wieku } \\
2 \text { lat u } 16 \text { niemowląt } \\
\text { z wentrikulomegalią } \\
\text { związaną } \\
\text { z przedporodowym } \\
\text { krwawieniem } \\
\text { dokomorowym. }\end{array}$ & $\begin{array}{c}\text { HINE } \\
\text { przeprowadzone } \\
\text { w } 2 \text { roku życia }\end{array}$ & $\begin{array}{c}\mathrm{n}=16(8 \hat{\jmath}, 89): 7 \\
\text { urodzonych przed } 33-36 \\
\text { tyg. ciąży. }\end{array}$ & Brak & $\begin{array}{c}\text { Badanie neurologiczne i ocena } \\
\text { neurorozwojowa (autorzy nie używali } \\
\text { nazwy HINE) w } 2 \text { roku życia: u } 8 \\
\text { niemowląt zdiagnozowano MPD (2 } \\
\text { z hemiplegią, } 1 \text { z diplegią, } \\
5 \text { z tetraplegią); u } 6 \text { padaczkę. } \\
\text { U } 8 \text { pacjentów wynik oceny } \\
\text { neurorozwojowej był w zakresie } \\
\text { normy. }\end{array}$ \\
\hline
\end{tabular}




\begin{tabular}{|c|c|c|c|c|c|}
\hline $\begin{array}{c}\text { Romeo i wsp. } \\
\text { (2008) } \\
{[21]}\end{array}$ & $\begin{array}{l}\text { 1. Ocena rozwoju } \\
\text { neuromotorycznego } \\
\text { w } 1 \text { roku życia za } \\
\text { pomocą HINE. } \\
\text { 2. Korelacja punktacji } \\
\text { ze skali HINE } \\
\text { z klasyfikacją GMFCS } \\
\text { (ang. Gross Motor } \\
\text { Function Classification } \\
\text { System). }\end{array}$ & $\begin{array}{c}\text { Badanie HINE } \\
\text { w } 3,6,9 \text { oraz } 12 \\
\text { miesiącu życia. }\end{array}$ & 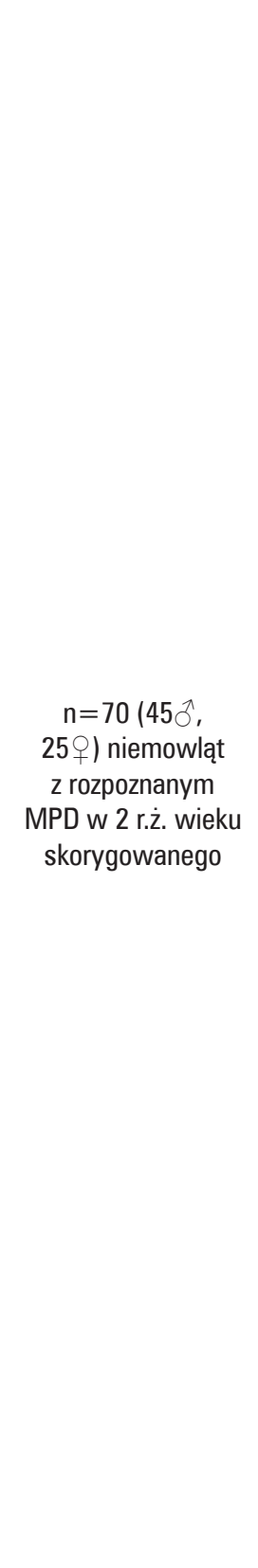 & $\begin{array}{c}\text { Rehabilitacja } \\
\text { 3-5/tydzień }\end{array}$ & 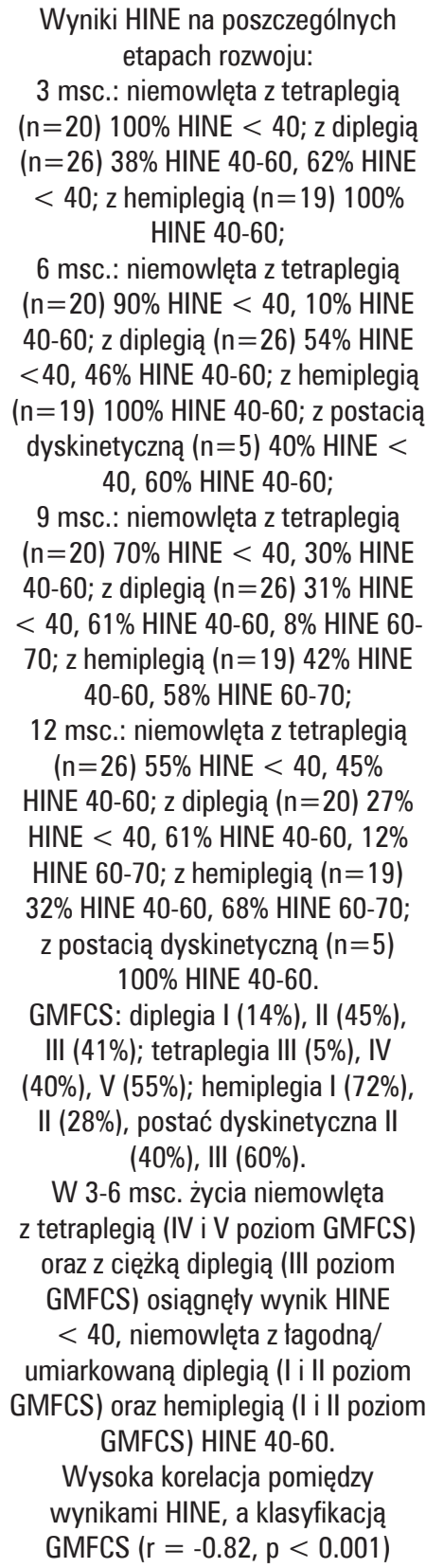 \\
\hline $\begin{array}{l}\text { Maunu i wsp. } \\
\text { (2011) } \\
{[15]}\end{array}$ & $\begin{array}{c}\text { Analiza związku } \\
\text { między wystąpieniem } \\
\text { poszerzenia komór } \\
\text { mózgu w terminie } \\
\text { planowanego porodu, } \\
\text { a wynikami oceny } \\
\text { neurorozwojowej } \\
\text { w wieku } 2 \text { lat (wiek } \\
\text { skorygowany) } \\
\text { u niemowląt z niską } \\
\text { masą urodzeniową } \\
\text { i/lub urodzonych } \\
\text { przedwcześnie. }\end{array}$ & $\begin{array}{l}\text { HINE, Bayley } \\
\text { Il przeprowa- } \\
\text { dzone w wieku } \\
2 \text { lat wieku } \\
\text { skorygowanego. }\end{array}$ & $\begin{array}{c}\mathrm{n}=225(121 \hat{\jmath} \\
104 \text {, }) \text { : średnia masa } \\
\text { urodzeniowa } 1133 \mathrm{~g}, \\
\text { średni wiek ciążowy } \\
29 \text { tyg. }\end{array}$ & Brak & $\begin{array}{l}\text { Badanie HINE przeprowadzono u } 215 \\
(96 \%) \text { niemowląt. } \\
\text { MPD: } n=15 \text { (7\%), w tym } 14 \text { z inną } \\
\text { patologią mózgu; uszkodzenia } \\
\text { słuchu: } n=12(5,3 \%) \text {; tagodne } \\
\text { opóźnienie funkcji poznawczych: } \\
\mathrm{n}=24(10,7 \%) \text {; ciężie opóźnienie } \\
\text { funkcji poznawczych: } n=8 \text { (3,6\%). } \\
\text { HINE ( } \mathrm{n}=215 \text {, wynik optymalny } \\
\text { dla dziecka w wieku } 18 \text { miesięcy, } \\
\text { urodzonego o czasie, to między } 74 \\
\text { i 78): dzieci bez innej patologii mózgu } \\
\text { (w tym } 1 \text { niemowlę z MPD) HINE } 74 . \\
\text { Dzieci z inną patologią mózgu (w tym } \\
14 \text { niemowląt z MPD) HINE 66-72. }\end{array}$ \\
\hline
\end{tabular}




\begin{tabular}{|c|c|c|c|c|c|}
\hline $\begin{array}{l}\text { Lind i wsp. } \\
\text { (2011) } \\
{[16]}\end{array}$ & $\begin{array}{c}\text { Ocena różnic } \\
\text { w objętości mózgu } \\
\text { u niemowląt z VLBW } \\
\text { (ang. very low birth } \\
\text { weight) bez zaburzeń } \\
\text { neurorozwojowych } \\
\text { takich jak: MPD, } \\
\text { znaczne upośledzenie } \\
\text { zdolności } \\
\text { poznawczych, utrata } \\
\text { słuchu i wzroku, } \\
\text { w porównaniu } \\
\text { do dzieci z VLBW } \\
\text { z zaburzeniami } \\
\text { neurorozwojowymi. } \\
\text { Ocena związku między } \\
\text { topograficznymi } \\
\text { objętościami } \\
\text { mózgu w terminie } \\
\text { planowanego } \\
\text { porodu, a rozwojem } \\
\text { poznawczym } \\
\text { i oceną neurologiczną } \\
\text { w wieku } 2 \text { lat (wiek } \\
\text { skorygowany). }\end{array}$ & $\begin{array}{l}\text { HINE, Bayley II } \\
\text { przeprowadzone } \\
\text { w wieku } 2 \\
\text { lat wieku } \\
\text { skorygowanego. }\end{array}$ & $\begin{array}{c}\mathrm{n}=164 \text { dzieci } \\
\text { z VLBW, w tym: } \\
\text { dzieci bez zaburzeń } \\
\text { neurorozwojowych } \\
\mathrm{n}=148 \text {, dzieci } \\
\text { z zaburzeniami } \\
\text { neurorozwojowymi } \\
n=16 \text {. }\end{array}$ & Brak & $\begin{array}{c}\text { Dzieci bez zaburzeń } \\
\text { neurorozwojowych: HINE } \geq 74 \text { : } \\
n=95(64 \%) \\
\text { HINE }<74: \mathrm{n}=53(36 \%) \\
\text { Dzieci z zaburzeniami } \\
\text { neurorozwojowymi: HINE } \geq 74 \text { : } \\
\mathrm{n}=2(13 \%) \\
\text { HINE }<74 \mathrm{n}=14 \text { (88\%) } \\
\mathrm{U} \text { dzieci bez zaburzeń } \\
\text { neurorozwojowych mniejsza } \\
\text { objętość móżdżku była istotnie } \\
\text { skorelowana z niskim wynikiem } \\
\text { w badaniu neurologicznym w } 2 \text { roku } \\
\text { życia wieku skorygowanego. } \\
\text { Objętość całkowitej tkanki } \\
\text { mózgowej, płatów czołowych, } \\
\text { zwojów podstawy i wzgórza oraz } \\
\text { móżdżku była istotnie mniejsza, } \\
\text { a objętość komór była istotnie } \\
\text { większa u dzieci z zaburzeniami } \\
\text { neurorozwojowymi niż u dzieci } \\
\text { bez towarzyszących zaburzeń. }\end{array}$ \\
\hline $\begin{array}{c}\text { Romeo i wsp. } \\
\text { (2013) } \\
{[17]}\end{array}$ & $\begin{array}{c}\text { Ocena badania } \\
\text { HINE jako narzędzia } \\
\text { predykcyjnego } \\
\text { dla wyników } \\
\text { neuromotorycznych } \\
\text { niemowląt wypisanych } \\
\text { z oddziału intensywnej } \\
\text { opieki noworodkowej. }\end{array}$ & $\begin{array}{l}\text { HINE w 3, 6, 9, } 12 \\
\text { msc. + badanie } \\
\text { neurologiczne wg } \\
\text { Touwena i Bayley } \\
\text { II w } 2 \text { roku życia. }\end{array}$ & $\begin{array}{c}\text { n=1541 noworodków } \\
\left(8167^{7} 725 \text { ) : średni }\right. \\
\text { wiek ciążowy } 36 \\
\text { tyg., średnia masa } \\
\text { urodzeniowa } 2500 \mathrm{~g} . \\
\text { W drugim roku życia } \\
\text { podział pacjentów na } \\
3 \text { grupy: prawidłowy } \\
\text { rozwój ( } \mathrm{n}=1150), \text { lekka } \\
\text { niepełnosprawność } \\
\text { (n=321), MPD ( }=70) \text {. }\end{array}$ & Brak & 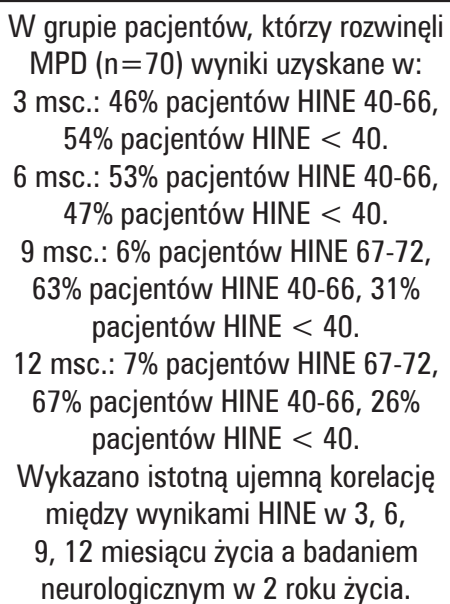 \\
\hline $\begin{array}{c}\text { Setänen i wsp. } \\
\text { (2014) } \\
{[22]}\end{array}$ & $\begin{array}{l}\text { Zbadanie wartości } \\
\text { predykcyjnej badania } \\
\text { neurologicznego } \\
\text { w połączeniu } \\
\text { z MRI w wieku } \\
\text { równoważnym } \\
\text { oraz serii USG } \\
\text { przezciemiączkowego } \\
\text { u dzieci urodzonych } \\
\text { przedwcześnie, dla } \\
\text { wyników badania } \\
\text { neurologicznego } \\
\text { w } 2 \text { roku życia wieku } \\
\text { skorygowanego. }\end{array}$ & $\begin{array}{c}\text { USG } \\
\text { przezcięmiączko- } \\
\text { we, badanie } \\
\text { neurologiczne } \\
\text { Dubowitza } \\
\text { i MRI - w wieku } \\
\text { równoważnym } \\
\text { HINE - } 2 \text { rok } \\
\text { życia (wiek } \\
\text { skorygowany). }\end{array}$ & $\begin{array}{c}\mathrm{n}=216(121 \AA \\
95 \bigcirc) \text { : średnia masa } \\
\text { urodzeniowa } 1132 \mathrm{~g}, \\
\text { średni wiek urodzenia } 29 \\
\text { 1/7 tygodnia }\end{array}$ & Brak & $\begin{array}{c}163 \text { niemowląt - } 1 \text { lub więcej } \\
\text { odchyleń w pierwszym badaniu } \\
\text { neurologicznym, } \\
176 \text { dzieci HINE > } 70 \\
\text { Średni wynik HINE: 73,9 } \\
17 \text { dzieci - zaburzenia } \\
\text { neurosensoryczne. } \\
\text { (MPD: } \mathrm{n}=14, \text { wszyscy min. } 1 \\
\text { odchylenie w badaniu w wieku } \\
\text { równoważnym, średni wynik HINE: } \\
54,3 \text { pkt). } \\
\text { Badanie neurologiczne podnosi } \\
\text { wartość predykcyjną MRI i USG. }\end{array}$ \\
\hline
\end{tabular}




\begin{tabular}{|c|c|c|c|c|c|}
\hline $\begin{array}{l}\text { Setänen i wsp. } \\
\text { (2016) } \\
{[23]}\end{array}$ & $\begin{array}{l}\text { Przewidywanie } \\
\text { sprawności } \\
\text { neuromotorycznej } \\
\text { u dzieci urodzonych } \\
\text { przedwcześnie na } \\
\text { podstawie badania } \\
\text { obrazowego } \\
\text { (MRI) i badań } \\
\text { neurologicznych. }\end{array}$ & $\begin{array}{c}\text { Badanie } \\
\text { neurologiczne } \\
\text { Dubowitza } \\
\text { i obrazowanie } \\
\text { MRI. } \\
\text { W wieku } 2 \text { lat } \\
\text { HINE. } \\
\text { W wieku } 11 \\
\text { lat: TINE (ang. } \\
\text { Touwen Infant } \\
\text { Neurological } \\
\text { Examination) }\end{array}$ & $\begin{array}{l}\mathrm{n}=98 ; \text { niemowlęta } \\
\text { urodzone przed } 37 \\
\text { tygodniem ciąży, } \\
\text { mediana masy } \\
\text { urodzeniowej: } 1083 \mathrm{~g}, \\
\text { ponownie badane } \\
\text { w wieku } 2 \text { i } 11 \text { lat }\end{array}$ & Brak & $\begin{array}{l}\text { U } 41 \text { dzieci wystąpiła prosta postać } \\
\text { MND (ang. Minor Neurological } \\
\text { Dysfunction), u } 11 \text { złożona postać } \\
\text { MND (cMND), a u } 8 \text { MPD. } \\
82 \text { badanych dzieci uzyskało } \\
\text { wynik HINE większy niż 70. Brak } \\
\text { informacji czy dzieci, które rozwinęły } \\
\text { zaburzenia to te osoby które uzyskały } \\
\text { wyniki HINE poniżej 70. Wartość } \\
\text { predykcyjna strukturalnego MRI } \\
\text { mózgu dla cMND lub MPD wynosiła } \\
\text { odpowiednio } 88 \% \text { i 50\%. }\end{array}$ \\
\hline $\begin{array}{l}\text { Hay i wsp. } \\
\text { (2018) } \\
{[24]}\end{array}$ & $\begin{array}{c}\text { Wykorzystanie } \\
\text { badania HINE i stopnia } \\
\text { nasilenia asymetrii } \\
\text { w celu zróżnicowania } \\
\text { niemowląt z hemiplegią } \\
\text { od rozwijających się } \\
\text { prawidłowo. }\end{array}$ & $\begin{array}{l}\text { HINE w 9-12 } \\
\text { miesiącu życia }\end{array}$ & $\begin{array}{c}\mathrm{n}=148, \text { w tym } \mathrm{n}=74 \\
\text { z MPD }\end{array}$ & Brak & $\begin{array}{l}\text { Mediana ogólnego wyniku HINE: } \\
\text { HINE 57,5 dla dzieci z hemiplegią } \\
(\mathrm{n}=35), \text { HINE } 63 \text { dla dzieci z diplegią } \\
(\mathrm{n}=11) \text {, HINE } 26 \text { dla dzieci } \\
\text { z tetraplegią ( } \mathrm{n}=28) \text {. } \\
\text { Wyniki asymetrii wahały się od } \\
6-17 \text { u dzieci z hemiplegią, } 0-3 \\
\text { u dzieci z diplegią i 0-15 u dzieci } \\
\text { z tetraplegią. Dzieci rozwijające się } \\
\text { prawidłowo miały sumaryczne wyniki } \\
\text { HINE }>62 \text { i asymetrię }<3 \text {. }\end{array}$ \\
\hline $\begin{array}{l}\text { Morgan i wsp. } \\
\text { (2019) } \\
{[9]}\end{array}$ & $\begin{array}{l}\text { Analiza efektywności } \\
\text { połączenia metod } \\
\text { neuroobrazowania } \\
\text { (MRI lub USG), oceny } \\
\text { globalnych wzorców } \\
\text { ruchowych wg } \\
\text { Prechtla i badania } \\
\text { HINE w celu wczesnej } \\
\text { diagnostyki MPD. }\end{array}$ & $\begin{array}{l}\text { Prechtl's GMA, } \\
\text { HINE w 3, 6, } 9 \\
\text { i } 12 \text { miesiącu } \\
\text { życia (w analizie } \\
\text { uwzględniono } \\
\text { jedynie HINE } \\
\text { przeprowadzone } \\
\text { w } 3 \text { miesiącu) }\end{array}$ & $\begin{array}{c}\mathrm{n}=441(220 \AA 221 \text { ( }) \text { : } \\
\text { w tym } \mathrm{n}=147 \mathrm{z} \mathrm{MPD}, \\
\text { średnia masa } \\
\text { urodzeniowa } 2130 \mathrm{~g} .\end{array}$ & Brak & $\begin{array}{c}\text { Mediana ogólnego wyniku HINE } \\
\text { w } 3 \text { msc.: } \\
\text { HINE } 63 \text { dla dzieci zdrowych } \\
\text { (n=147), HINE } 57 \text { dla dzieci z lekką } \\
\text { niepełnosprawnością (n=147), } \\
\text { HINE } 46 \text { dla dzieci z MPD (n=147) } \\
\text { Mediana ogólnego wyniku HINE } \\
\text { w } 12 \text { msc.:HINE } 72 \text { dla dzieci } \\
\text { zdrowych, HINE } 59 \text { dla dzieci z MPD. } \\
\text { Czułość i swoistość wykrywania } \\
\text { MPD wyniosła: } 88 \% \text { i } 62 \% \text { dla HINE } \\
\text { wykonanego w } 3 \text { msc., 95\% i 97\% } \\
\text { dla globalnych wzorców ruchu } \\
\text { wg Prechtla oraz 79\% i 99\% dla } \\
\text { neuroobrazowania. Połączona moc } \\
\text { predykcyjna wszystkich trzech ocen } \\
\text { dała czułości i swoistości na poziomie } \\
\text { 98\% i 99\%. }\end{array}$ \\
\hline $\begin{array}{l}\text { Romeo i wsp. } \\
\text { (2020) } \\
{[10]}\end{array}$ & $\begin{array}{l}\text { Ocena skuteczności } \\
\text { i użyteczności HINE } \\
\text { w rozpoznawaniu } \\
\text { typowego } \\
\text { i opóźnionego } \\
\text { rozwoju poznawczego } \\
\text { w populacji dzieci z/ } \\
\text { bez MPD. }\end{array}$ & $\begin{array}{l}\text { HINE w 3, 6, 9, } 12 \\
\text { miesiącu życia. } \\
\text { Bayley II w wieku } \\
2 \text { lat wieku } \\
\text { skorygowanego. }\end{array}$ & $\begin{array}{c}\mathrm{n}=1229 \text { niemowląt } \\
\left(646{ }^{-}, 583 \text { ) }\right): \\
\text { wiek ciążowy } 25-36 \\
\text { tyg. (średnia } 34,9 \text { tyg.), } \\
\text { masa urodzeniowa } 630 \\
\mathrm{~g}-4570 \mathrm{~g} \text { (średnia } \\
2256 \mathrm{~g})\end{array}$ & Brak & $\begin{array}{c}\text { Dzieci z MPD: badanie w } 3 \text { msc. HINE } \\
\text { < 57, w } 12 \text { msc. HINE < 66. } \\
\text { Opóźnienie rozwoju poznawczego } \\
\text { i/lub MPD: w } 3 \text { msc. HINE < 58, } \\
\text { w } 6 \text { msc. HINE < 64, w } 9 \text { i } 12 \text { msc. } \\
\text { HINE < 69. HINE wykazało wysoką } \\
\text { czułość i swoistość predykcji } \\
\text { znacznego opóźnienia funkcji } \\
\text { poznawczych (zwłaszcza badanie } \\
\text { w } 3 \text { msc.), szczególnie w grupie } \\
\text { dzieci bez MPD. Ocena Bayley II: } \\
n=1108 \text { dzieci bez diagnozy MPD: } \\
n=891 \text { wskaźnik MDI (ang. Mental } \\
\text { Developmental Index) > 70, } n=217 \\
\text { MDI < 70, } n=121 \text { dzieci rozwinęło } \\
\text { MPD, w tym: } n=28 \text { MDI } \geq 85, n=27 \\
\text { MDI 70-84, } n=60 \text { MDI }<70 \text {. }\end{array}$ \\
\hline
\end{tabular}




\begin{tabular}{|c|c|c|c|c|c|}
\hline $\begin{array}{c}\text { de Carvalho A. } \\
\text { i wsp. (2020) } \\
{[25]}\end{array}$ & $\begin{array}{c}\text { 1. Ocena } \\
\text { neurorozwojowa } \\
\text { u dzieci } \\
\text { z MPD związanym } \\
\text { z zakażeniem wirusem } \\
\text { Zika. } \\
\text { 2. Wskazanie } \\
\text { zmiennych związanych } \\
\text { z wystąpieniem } \\
\text { cięższej postaci MPD. }\end{array}$ & $\begin{array}{l}\text { Bayley III, HINE } \\
\text { w } 24 \text { miesiącu } \\
\text { życia }\end{array}$ & $\begin{array}{c}\mathrm{n}=69(33 \hat{\jmath}, 36 \text { ) } \\
\text { dzieci z MPD związanym } \\
\text { z chorobą Zika, mediana } \\
\text { wieku w okresie } \\
\text { obserwacji wynosita } 24 \\
(23-32) \text { miesiące, } \\
\text { mediana masy } \\
\text { urodzeniowej wynosiła } \\
2700 \mathrm{~g}(1300 \text { - } 3900 \mathrm{~g}) .\end{array}$ & Brak & $\begin{array}{c}65 \text { dzieci z postacią bilateralną MPD } \\
\text { (94,2\%), a } 4 \text { unilateralną (5,8\%), } \\
64 \text { dzieci z MPD GMFCS IV lub V } \\
\text { (92,8\%), } 5 \text { z MPD GMFCS I lub II. } \\
\text { Mediana ogólnego wyniku w badaniu } \\
\text { HINE } 21 \text { (zakres 9-75). } \\
\text { HINE } 19 \text { (zakres 9-43) dla dzieci } \\
\text { z porażeniem czterokończynowym. } \\
\text { HINE 69,5 (zakres 63-75) wśród } \\
\text { pozostałych niemowląt. }\end{array}$ \\
\hline $\begin{array}{l}\text { Harpster i wsp. } \\
\text { (2021) [26] }\end{array}$ & $\begin{array}{c}\text { Ocena występowania } \\
\text { i związku między } \\
\text { nieprawidłowym } \\
\text { wynikiem } \\
\text { strukturalnego MRI, } \\
\text { nieobecnością fidgety } \\
\text { movements (GMA) } \\
\text { i nieprawidłowym } \\
\text { badaniem HINE } \\
\text { w 3-4 miesiącu } \\
\text { życia u niemowląt } \\
\text { urodzonych } \\
\text { przedwcześnie. }\end{array}$ & $\begin{array}{l}\text { Prechtl's GMA, } \\
\text { HINE w 3-4 } \\
\text { miesiącu wieku } \\
\text { skorygowanego, } \\
\text { MRI w wieku } \\
\text { równoważnym. }\end{array}$ & $\begin{array}{c}\mathrm{n}=392\left(210{ }^{2}, 182+\right) ; \\
(15 \text { niemowląt zostało } \\
\text { wyłączonych z badania } \\
\text { z powodu niepełnych } \\
\text { danych); średnia masa } \\
\text { urodzeniowa wynosiła } \\
1294 \text { g.; średni wiek } \\
\text { ciążowy wynosił } 29,3 \\
\text { tygodnia. }\end{array}$ & Brak & $\begin{array}{c}\text { Spośród } 375 \text { niemowląt: } 44 \text { (12\%) } \\
\text { wykazało umiarkowane lub ciężkie } \\
\text { zaburzenia mózgu, } 17(4,5 \%) \text { miało } \\
\text { nieprawidłowy wynik GMA, } 77 \\
(20,3 \%) \text { miało nieprawidłowy wynik } \\
\text { HINE. } \\
\text { Wyniki HINE zakres od 30,5 do } 73 \\
\text { (mediana 60). } \\
27 \text { niemowląt (7\%) miało } \\
\text { nieprawidłowości w co najmniej } \\
2 \text { z } 3 \text { badań (nieprawidłowe MRI, } \\
\text { nieprawidłowy wynik GMA i/lub } \\
\text { wynik HINE < 56); } 9 \text { (2\%) wykazało } \\
\text { nieprawidłowości we wszystkich } 3 \\
\text { testach. Wyniki MRI były istotnie } \\
\text { skorelowane z GMA i HINE. Istnieje } \\
\text { niska korelacja (R² = 0,14) między } \\
\text { wynikami GMA a HINE. Zaleca } \\
\text { się stosowanie obu narzędzi } \\
\text { w połączeniu z MRI, a nie zamiennie. }\end{array}$ \\
\hline $\begin{array}{c}\text { King i wsp. } \\
\text { (2021) } \\
{[18]}\end{array}$ & $\begin{array}{c}\text { Określenie } \\
\text { częstotliwości } \\
\text { rozpoznawania MPD } \\
\text { u niemowląt. }\end{array}$ & $\begin{array}{l}\text { Prechtl's GMA, } \\
\text { HINE w } 3 \\
\text { miesiącu wieku } \\
\text { skorygowanego }\end{array}$ & $\begin{array}{c}\mathrm{n}=96(55 \hat{,}, 41 \text { ) }): \\
\text { I grupa: } \mathrm{n}=68(71 \%) \\
\text { urodzone przed } 29 \mathrm{tyg} \text {. } \\
\text { lub masa ciała poniżej } \\
1000 \mathrm{~g} ; \\
\text { II grupa: } \mathrm{n}=28(29 \%) \\
\text { umiarkowane lub ciężkie } \\
\text { uszkodzenia mózgu; } \\
\text { w } 3 \text { miesiącu wieku } \\
\text { skorygowanego. }\end{array}$ & Brak & $\begin{array}{c}\text { MPD zdiagnozowano u } 9 \text { (9,6\%) } \\
\text { badanych - } 2 \text { z grupy I i } 7 \text { z grupy II; } \\
\text { wysokie ryzyko wystąpienia MPD } \\
\text { u } 12 \text { badanych }(12,5 \%) \text { - } 7 \text { z grupy } \\
\text { I i } 5 \text { z grupy II. } \\
\text { Mediana ogólnego wyniku HINE } 60 \\
\text { (56,3-63,0) dla dzieci z typowym } \\
\text { rozwojem; HINE 50,0 (45,0-52,0) } \\
\text { dla dzieci z opóźnionym rozwojem; } \\
\text { HINE 45,5 (40,8-47,5) dla dzieci } \\
\text { z wysokim ryzykiem MPD; HINE } 34 \\
\text { (26,8-45) dla dzieci z MPD. }\end{array}$ \\
\hline
\end{tabular}

zyczną (http://hammersmith-neuro-exam.com/wp-content/ uploads/2020/06/HINE-Polish-translation_28.05.2020. pdf). Badanie HINE jest dobrą alternatywą, bądź uzupełnieniem dla innych, bardziej kosztownych badań. Wszystkie te aspekty przekonują o istotności badania HINE $\mathrm{w}$ ocenie i przewidywaniu rozwoju neuromotorycznego dzieci ze szczególnym uwzględnieniem pacjentów z grup ryzyka $[5,8,33,34]$.

\section{PIŚMIENNICTWO}

[1] Rosenbaum P.L, Paneth N., Leviton A., et al.: The definition and classification of cerebral palsy. Dev Med Child Neurol. 2007; 49(s109): 1-44.

[2] Sankar C., Mundkur, N.: Cerebral palsy-definition, classification, etiology and early diagnosis. Indian J Pediatr 2005; 72: 865-868.

[3] Michael-Asalu A., Taylor G., Campbell H., et al.: Cerebral Palsy: Diagnosis, Epidemiology, Genetics, and Clinical Update. Adv Pediatr. 2019; 66: 189208.

[4] Salandy S., Rai R., Gutierrez S., et al.: Neurological examination of the infant: A Comprehensive Review. Clin Anat. 2019; 32: 770-777.
[5] Romeo D.M., Ricci D., Brogna C.,, et al.: Use of the Hammersmith Infant Neurological Examination in infants with cerebral palsy: a critical review of the literature. Dev Med Child Neurol 2016; 58: 240-245.

[6] Pizzardi A., Romeo D.M., Cioni M., et al.: Infant neurological examination from 3 to 12 months: predictive value of the single items. Neuropediatrics. 2008; 39: 344-346.

[7] Dubowitz L., Mercuri E., Dubowitz V.: An optimality score for the neurologic examination of the term newborn. J Pediatr. 1998; 133: 406-416.

[8] Novak I., Morgan C., Adde L., et al. Early, Accurate Diagnosis and Early Intervention in Cerebral Palsy: Advances in Diagnosis and Treatment. JAMA Pediatr. 2017; 171: 897-907.

[9] Morgan C., Romeo D.M., Chorna 0., et al.: The Pooled Diagnostic Accuracy of Neuroimaging, General Movements, and Neurological Examination for Diagnosing Cerebral Palsy Early in High-Risk Infants: A Case Control Study. J Clin Med 2019; 8: 1879.

[10] Romeo D.M., Cowan F.M., Haataja L., et al.: Hammersmith Infant Neurological Examination for infants born preterm: predicting outcomes other than cerebral palsy. Dev Med Child Neurol. 2020 Dec 18.

[11] Haataja L., Mercuri E., Regev R., et al.: Optimality score for the neurologic examination of the infant at 12 and 18 months of age. J Pediatr. 1999; 135(2 Pt 1): 153-161. 
[12] Haataja L., Cowan F., Mercuri E., et al.: Application of a scorable neurologic examination in healthy term infants aged 3 to 8 months. $J$ Pediatr. 2003; 143: 546.

[13] Moher D., Liberati A., Tetzlaff J., et al.: Preferred reporting items for systematic reviews and meta-analyses: the PRISMA Statement. PLoS Med 2009; 3: e123-30.

[14] Williams S.A., Mackey A., Sorhage A., et al.: Clinical practice of health professionals working in early detection for infants with or at risk of cerebral palsy across New Zealand. J Paediatr Child Health. 2021; 57: 541-547.

[15] Maunu J., Lehtonen L., Lapinleimu H., et al.: Ventricular dilatation in relation to outcome at 2 years of age in very preterm infants: a prospective Finnish cohort study. Dev Med Child Neurol. 2011; 53: 48-54.

[16] Lind A., Parkkola R., Lehtonen L., et al.: Associations between regional brain volumes at term-equivalent age and development at 2 years of age in preterm children. Pediatr Radiol. 2011; 41: 953-961.

[17] Romeo D.M., Cioni M., Palermo F., et al.: Neurological assessment in infants discharged from a neonatal intensive care unit. Eur J Paediatr Neurol. 2013; 17: 192-198.

[18] King A.R., Machipisa C., Finlayson F., et al.: Early detection of cerebral palsy in high-risk infants: Translation of evidence into practice in an Australian hospital. J Paediatr Child Health. 2021; 57: 246-250.

[19] Ricci D., Cowan F., Pane M., et al.: Neurological examination at 6 to 9 months in infants with cystic periventricular leukomalacia. Neuropediatrics. 2006; 37: 247-252.

[20] Luciano R., Baranello G., Masini L., et al.: Antenatal post-hemorrhagic ventriculomegaly: a prospective follow-up study. Neuropediatrics. 2007; 38: $137-142$.

[21] Romeo D.M., Cioni M., Scoto M., et al.: Neuromotor development in infants with cerebral palsy investigated by the Hammersmith Infant Neurological Examination during the first year of age. Eur $\mathrm{J}$ Paediatr Neurol. 2008; 12: 24-31.

[22] Setänen S., Lahti K., Lehtonen L., et al.: Neurological examination combined with brain MRI or cranial US improves prediction of neurological outcome in preterm infants. Early Hum Dev. 2014; 90: 851-856.
[23] Setänen S., Lehtonen L., Parkkola R., et al.: Prediction of neuromotor outcome in infants born preterm at 11 years of age using volumetric neonatal magnetic resonance imaging and neurological examinations. Dev Med Child Neurol. 2016; 58: 721-727.

[24] Hay K., Nelin M., Carey H., et al.: Hammersmith Infant Neurological Examination Asymmetry Score Distinguishes Hemiplegic Cerebral Palsy From Typical Development. Pediatr Neurol. 2018; 87: 70-74.

[25] Carvalho A.L., Ventura P., Taguchi T., et al.: Cerebral Palsy in Children With Congenital Zika Syndrome: A 2-Year Neurodevelopmental Follow-up. J Child Neurol. 2020; 35: 202-207.

[26] Harpster K., Merhar S., Priyanka Illapani V.S., et al.: Associations Between Early Structural Magnetic Resonance Imaging, Hammersmith Infant Neurological Examination, and General Movements Assessment in Infants Born Very Preterm. J Pediatr. 2021; 232: 80-86.

[27] Romeo D.M., Guzzetta A., Scoto M., et al.: Early neurologic assessment in preterm-infants: integration of traditional neurologic examination and observation of general movements. Eur J Paediatr Neurol. 2008; 12: 183-189.

[28] Uusitalo K., Haataja L., Nyman A., et al. Hammersmith Infant Neurological Examination and long-term cognitive outcome in children born very preterm. Dev Med Child Neurol. 2021 Apr 8.

[29] Oudgenoeg-Paz O., Mulder H., Jongmans M.J., et al.: The link between motor and cognitive development in children born preterm and/or with low birth weight: A review of current evidence. Neurosci Biobehav Rev. 2017; 80: 382-393.

[30] Bos A.F.: Early neuromotor performance and later cognition in children born preterm. Dev Med Child Neurol. 2021 May 6.

[31] Libertus K., Hauf P. Editorial: Motor Skills and Their Foundational Role for Perceptual, Social, and Cognitive Development. Front Psychol. 2017; 8: 301.

[32] Maitre N.L., Chorna O., Romeo D.M., et al.: Implementation of the Hammersmith Infant Neurological Examination in a High-Risk Infant Follow-Up Program. Pediatr Neurol. 2016; 65: 31-38.

[33] Eliks M., Gajewska E.: Wczesna diagnostyka mózgowego porażenia dziecięcego. Czy jest możliwa już w pierwszym półroczu życia? Neurol Dziec 2019; 57: 29-33.

Adres do korespondencji:

Jakub S. Gąsior, jgasior@wum.edu.pl, 793-199-222, Klinika Kardiologii Wieku Dziecięcego i Pediatrii Ogólnej, Warszawski

Uniwersytet Medyczny, ul. Żwirki i Wigury 63A, 02-091 Warszawa 